\title{
Event structure of complex predicates with the light verb lart 'seat, put' in Poshkart Chuvash
}

\section{F. V. Golosov}

HSE University (Moscow, Russia); golosovfv@gmail.com

\begin{abstract}
This article addresses the semantic properties and selective restrictions of the grammaticalized verb lart 'seat, put' in the Poshkart dialect of Chuvash. I show that the light verb can combine with lexical verbs with external arguments to form telic complex predicates signaling significant scalar change of state of one of the arguments. A description of the different behavior the light verb lart demonstrates with verbs that already have a scale of change and those that lack it is proposed. Further, I offer a formal analysis of the event structure of complex predicates with lart undertaken in the first phase syntax framework. The light verb lart has an impoverished event structure of its own that consists of three eventual heads (init, proc, and res) with Initiator, Undergoer, and Resultee as their specifiers. As the paper shows, this analysis predicts both the selective restrictions of the light verb and the resulting semantics of the complex predicates. In particular, the suggested analysis predicts the distribution of the two basic (the gradative and the accumulative) meanings of the light verb lart. I claim that these meanings can be reduced to a single meaning of a scalar change of the state affecting the Undergoer of the event. The gradative meaning arises in contexts where the Undergoer is non-coreferential to the Initiator and the accumulative meaning, in contexts where the Initiator is coreferential to the Undergoer. The data were collected by elicitation during my field trip to the Chuvash village of Poshkart (Maloye Karachkino).
\end{abstract}

Keywords: complex predicates, serialization, grammaticalization, Chuvash, actionality, event structure, accumulative, gradative.

Acknowledgments: The research is supported by the grant RFBR 20-512-14003 "Language diversity in Volga Sprachbund. Typology of grammatical phenomena and language contacts". 


\section{Структура события сложных глаголов с легким глаголом lart 'посадить, поставить' в малокарачкинском диалекте чувашского языка}

\section{Ф. В. Голосов}

Национальный исследовательский университет «Высшая школа экономики» (Москва, Россия); golosovfv@gmail.com

Аннотация. Статья посвящена семантическим особенностям и селективным ограничениям грамматикализованного глагола lart ‘посадить, поставить' в малокарачкинском говоре чувашского языка. В статье показывается, что этот легкий глагол сочетается с лексическими глаголами с внешним аргументом и образует предельные сложные предикаты со значением заметного изменения состояния одного из участников события по некоторой шкале. Кроме этого, предлагается предварительный анализ структуры события сложных глаголов с lart в рамках синтаксиса первой фазы, объясняющий селективные ограничения сложного глагола и дистрибуцию двух основных его значений: собственно градативного и аккумулятивного.

Ключевые слова: сложные глаголы, сериализация, грамматикализация, чувашский язык, акциональность, аспект, структура события, аккумулятив, градатив.

\section{Introduction}

Chuvash features complex predicates that represent constructions consisting of two verbal forms denoting a single event (1):

(1)

$$
\begin{array}{lll}
\text { vacə } & \text { cur-za } & \text { lart-rij-ə } \\
\text { V. } & \text { sleep-CV_SIM } & \text { seat-PST-3SG } \\
\text { 'Vasya slept enough'. }
\end{array}
$$


The meaning of (1) differs from what could be expected: the verb lart ${ }^{1}$ 'seat, put' does not describe a situation of seating or putting. It is used in this sentence as a so-called light verb that, rather than describing a separate situation, modifies the event structure of the verb used in the converbal form, also labeled a lexical verb.

Complex predicates are widespread in Turkic languages (see, e.g., [Grashchenkov 2015]), including in Chuvash. The semantics of and selective restrictions on light verbs in Chuvash have been a focus of many studies ([Ashmarin 1923; Yegorov 1957; Lebedev 2016, etc.]). A notable work is [Shluinskiy 2006], describing the meaning of the light verb il 'take' in combination with lexical verbs of different actional classes. Most light verbs, however, still lack a detailed description or theoretical understanding: only some general facts about their meaning and distribution are known, and no minimal pairs are provided to corroborate these generalizations.

This paper describes the selection restrictions and the actional semantics of the light verb lart 'seat, put', proposing a formal analysis to systemize and explain its behavior. I argue that the light verb lart is a telicizing operator which forms punctive complex predicates denoting a significant change of a state associated with some scale. My analysis of the light verb lart in consistence with the first phase syntax theory will show that the light verb lart has its own impoverished event structure defining its selectional restrictions and actional semantics.

The paper is structured as follows. After an introduction in Section 1, Section 2 provides an overview of the existing literature on the light verb lart. Section 3 lays out the methodology of the research. The data are presented in Section 4 with three subsections where Subsection 4.1 describes the general properties of complex predicates with lart, Subsection 4.2 looks into the light verb's relations with incremental lexical verbs, and Subsection 4.3 discusses the behavior of the light verb with non-incremental lexical verbs. Section 5 proposes a final analysis, and Section 6 draws conclusions and presents perspectives for future research.

\footnotetext{
${ }^{1}$ Henceforth, I use the bare stem of a Chuvash verb as its lemma.
} 


\section{Literature review}

One of the first mentions of the light verb lart 'seat' seems to belong to Ashmarin [1923]. He describes this light verb together with its intransitive variant lar 'sit down' as denoting "seat, sitting $\langle\ldots\rangle$ or fixed position, $\langle\ldots\rangle$ entering a hopeless, miserable, inert, or disastrous state" ${ }^{2}$.

In his dissertation on aspectual light verbs in Chuvash, E. Lebedev [2016] also addresses the light verb lart. In his study, Lebedev describes the various actionality meanings of light verbs and their interaction with verbs of different lexical classes. According to Lebedev, light verbs lart 'seat' and lar 'sit down, sit' represent a single element lar $(t)$ encoding "an actional meaning of the end of an action" 3 , especially in its causative variant. These light verbs combine with two classes of lexical predicates: inactive atelic and active telic verbs. The examples provided show the former to only combine with lar 'sit down', and the latter, to also combine with lart 'seat'. Finally, Lebedev claims that "the actional meaning of this element is supplemented with the meaning of effectiveness of action" ${ }^{4}$.

Overall, the existing works on the light verb lart demonstrate its general actional nature: it is grammaticalized into a telicizing operator which preferably combines with agentive lexical verbs (while patientive lexical verbs prefer its intransitive counterpart, the light verb lar 'sit down'). This description is, however, too holistic and lacks reliable proof: we do not see, for instance, any inverse examples where this light verb would occur in atelic contexts or combine with patientive light verbs. In addition, the exact meaning of this light verb is not specified, so that it is not clear if: it a) differs from the other telicizing light verbs, b) its meaning is always the same, c) it depends on some properties of a lexical verb, or d) there are any other restrictions on the contexts where the light verb lart can occur.

2 «[С]идение, сидячее $\langle\ldots\rangle$ или неподвижное положение; $\langle\ldots\rangle$ попадание в безысходное, жалкое, инертное или бедственное положение» [Ashmarin 1923: 48].

${ }^{3}$ «[А]кционсартовое значение окончания действия» [Lebedev 2016: 86].

${ }^{4}$ «Акционсартовое значение данной формы дополнено смыслом результативности совершения действия» [Lebedev 2016: 86]. 
In a bid for an answer to all these questions, this paper proposes a detailed description of the general actional behavior of the light verb lart, its selectional restrictions, and its different meanings arising in combination with various classes of lexical verbs, as well as a formal analysis predicting the results observed.

\section{Methodology}

The examples used in this paper were collected by elicitation during my fieldwork in the Chuvash village of Poshkart (Maloye Karachkino) in August 2019 and in March 2020. My consultants were native speakers of the local Poshkart Chuvash dialect differing from the Standard Chuvash in many respects. Thus, all my generalizations are only based ${ }^{5}$ on Poshkart Chuvash.

Two methods of elicitation were employed: I asked my consultants to translate a Russian sentence into Chuvash, or asked them to rate the acceptability of a Chuvash sentence (and translate it, if the sentence was interpretable). The examples obtained sometimes differ in their acceptability for different speakers, as reflected in the specific notes in the text below in some cases.

Examples, collected from and approved by at least three different consultants, are taken as grammatically felicitous and provided below without any acceptability indications. Examples collected from less than three consultants, are marked in the text as preliminary to mean that their acceptability rate may change based on other native speakers' judgement.

If an obtained example shows inconsistent evaluation, it is prefixed by ${ }^{\%}$ where the numbers of positive and negative judgements are split evenly, or by ?? where most estimations were negative. All examples consistently estimated as negative are marked by * or ${ }^{\#}$, depending on their grammatical or pragmatic infelicity, respectively.

${ }^{5}$ Notably, all my consultants also speak Standard Chuvash, so that there could be minor inclusions of particular Standard Chuvash words in some examples. 
Finally, some examples, evaluated as acceptable but not entirely natural, are marked by ? These are viewed as tentatively grammatically felicitous with a view to possible accommodation difficulties. Notably, the nature of the constructions addressed here makes it difficult to expect a general consensus with respect to their felicity/infelicity among native speakers.

\section{The data}

This section consists of three parts. The first part considers the general properties of the complex predicates with lart: their general actional meanings, semantics, and selection restrictions. The following two parts look into the behavior of lart with incremental and non-incremental lexical verbs, respectively.

Many tests used in this section were developed for an analysis of the Hill Mari light verb šändäš 'seat, put' [Kashkin 2018a, 2018b; Golosov 2019], since lart turnes out to have a lot in common with its Hill Mari counterpart. I will briefly comment on this similarity in the concluding remarks.

\subsection{The general properties of complex predicates with lart}

The lexical meaning of the verb lart is 'seat, put' (2):

$\begin{array}{lllll}\text { vacə } & \text { vaz-in-e } & \text { sëdel } & \text { 6i-n-e } & \text { lart-rij-a } \\ \text { V. } & \text { vase-P_3-овJ } & \text { table } & \text { surface-P_3-овJ } & \text { seat-PST-3sG }\end{array}$

'Vasya put the vase on the table'.

As a light verb, it has been grammaticalized into a telicizing operator that forms punctual complex predicates:

$$
\begin{array}{lllll}
\text { a. vacə } & \text { pilëk } & \text { minut-ra } & \text { ci-ze } & \text { lart-rír- } \\
\text { V. } & 5 & \text { minute-LOC } & \text { eat-CV_SIM } & \text { seat-PST-3SG } \\
\text { 'Vasya ate enough in five minutes'. }
\end{array}
$$


$\begin{array}{ccccc}\text { b. *vacə } & \text { pilëk } & \text { minut } & \text { 6i-ze } & \text { lart-rij-a } \\ \text { V. } & 5 & \text { minute } & \text { eat-CV_SIM } & \text { seat-PST-3SG }\end{array}$

Int.: 'Vasya satisfied his hunger by eating for five minutes'.

c. vaco $6 i$-ze lard-at

V. eat-CV_SIM seat-NPST.3sG

'Vasya will satisfy his hunger/*is satisfying his hunger'.

In (3), I demonstrate that the complex predicates with lart are punctives $^{6}$ in the sense of [Tatevosov 2016], i.e. they belong to the actional class $<$ ES, - $>$, always denoting a culmination point. This is illustrated by the traditional adverbial and progressive interpretation tests: a complex predicate size lart in the past tense $(3 \mathrm{a}-\mathrm{b})$ can combine with timespan adverbials but cannot combine with durative ones. In the non-past tense (3c), it does not have a progressive interpretation.

The general semantic property of complex predicates with lart is that they denote a scalar change of the undergoer's state (4):

$$
\begin{array}{llll}
\text { vacə } & \text { su } & \text { azət-sa } & \text { lart-r'j-ə } \\
\text { V. } & \text { water } & \text { heat-CV_sIm } & \text { seat-PST-3SG } \\
\text { 'Vasya heated the water'. }
\end{array}
$$

In (4), the water changes its properties along a temperature scale or, to be precise, the water's temperature grows to some contextually relevant degree.

The degree of change must be contextually high and significant. This is illustrated by asymmetric compatibility with adverbials of different degree. Namely, complex predicates with lart, quite felicitous with adverbials of high degree, are less so with those of low degree:

$$
\begin{array}{lll}
\text { a. val nomaj ë6-se lart-rí-a } \\
\text { 3sG many drink-CV_SIM } & \text { seat-PST-3SG } \\
\text { 'He drank a lot'. }
\end{array}
$$

${ }^{6}$ Note that "punctive" in this use does not mean "momentary". A punctive predicate can denote only a culmination point of an event, but this does not entail that the event itself is momentary: complex predicates with lart can combine with term-span adverbials as in (3a). 
b. ${ }^{\#}$ val sagal ë6-se lart-rij-a

h3sG little drink-CV_SIM seat-PST-3SG

Int.: 'He drank little'.

(6)
a. ebë nomaj xot cët-se lart-r-əm
$1 \mathrm{SG}$ many paper tear-CV_SIM seat-PST-1SG
'I tore a lot of paper'.

b. ${ }^{\%} \mathrm{ep}^{7}$ sagal xot eёt-se lart-r-əm

1SG little paper tear-CV_SIM seat-PST-1SG

Int.: 'I tore a little paper'.

(7) a. samaljot pin kilometr vë6-se lart-sa

plane $\quad 1000$ kilometer fly-Cv_sIM seat-CV_SIM

'A plane flew one thousand kilometers'.

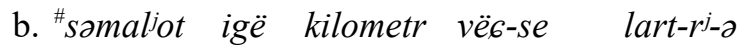

plane $\quad 2$ kilometer fly-CV_SIM seat-PST-3sG

Int.: 'A plane flew two kilometers'.

Thus, it is possible to mark a high grade of saturation as in (5a), a large volume of the accumulated object as in (6a), or a contextually long path covered as in (7a), while examples denoting a low degree of saturation, a smaller volume of the accumulated object, or a contextually short path covered are infelicitous. For instance, my consultants find (7b) pragmatically strange: our experience tells us that two kilometers is too insignificant a path for any plane. Such restrictions do not seem to apply to isolated lexical verbs.

The light verb lart shows restrictions on the argument structure of lexical verb. Namely, it can combine with transitive, agentive, or stative lexical verbs, i.e. verbs that have an external argument in terms of, for instance, [Ramchand 2008a], while it cannot combine with patientive verbs, i.e. verbs denoting an uncontrolled change of state:

$$
\begin{array}{llll}
\text { a. vacə oj } & \text { soxala-za } & \text { lart-ríz-ə } \\
\text { V. } & \text { field } & \text { plow-CV_SIM } & \text { seat-PST-3SG } \\
\text { 'Vasya plowed the field'. }
\end{array}
$$

\footnotetext{
7 The pronunciation of the first singular personal pronoun is variative.
} 


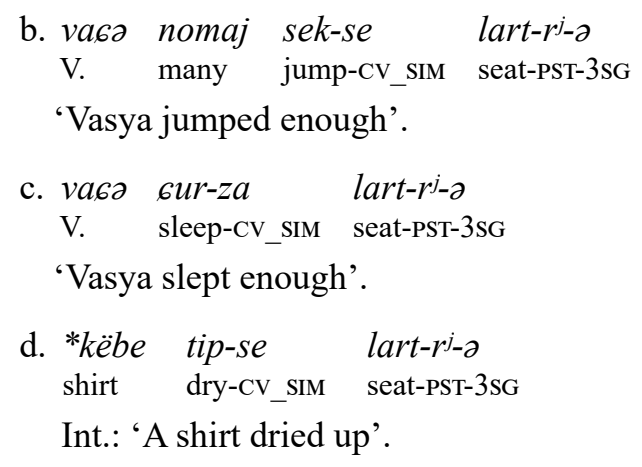

In (8a), the light verb lart combines with the transitive verb soxala 'plow'; in (8b), with the verb sek 'jump' denoting an agentive process; and in (8c), with the state verb cur 'sleep'. It cannot combine, however, with lexical verbs denoting a change of state of the patient, such as tip 'dry' in (8d) where the synonymous light verb lar 'sit down' is used instead:
a. man
6y6 tip-se lar-t6-26
1SG.GEN hair dry-CV_SIM sit.down-PST-3PL
'My hair dried'.

$\begin{array}{lll}\text { b. } s u & \text { azan-za } & \text { lar-t6-a } \\ \text { water } & \text { heat-CV_SIM } & \text { sit.down-PST-3sG }\end{array}$

'The water heated'.

The exact set of distribution rules or the way it aligns with the other unaccusativity diagnostics remains, however, unclear. This problem needs further research. Nevertheless, I will preliminarily identify patientive intransitives with unaccusatives and agentive intransitives with unergatives.

The light verb lart combines with different lexical verbs with varying semantic impact on the meaning, partially depending on whether they already have a scalar argument. Below, I will first consider the verbs that already have a kind of a scalar argument, i.e. incremental verbs, and then discuss the way the light verb interacts with non-incremental lexical verbs. 


\subsection{The light verb lart and incremental lexical verbs}

Before a description of the data obtained, a brief theoretical introduction for incremental verbs will be in order here. The notion of incrementality was first introduced in [Krifka 1989, 1992]. Krifka defines incrementality as a one-to-one relation between an event and its argument (10):

(10) John ate an apple.

The sentence in (10) describes an event of eating, where the object, an apple, undergoes a change (disappears) in the course of the event. The relation between the event and the object is incremental, since each part of the event corresponds to some unique part of the object, and vice versa. A verb with an argument incremental with respect to the event is labeled an incremental verb.

There are three types of incremental arguments: an incremental theme, an incremental property, and an incremental path; see, for instance, [Tatevosov 2015]. An incremental theme is an argument whose parts are involved in the incremental relation to the event. Thus, (10) shows a one-toone relation between the event of eating and the parts of the apple. Another example of a verb with an incremental theme is (11):

(11) The house burnt.

Here, the house is also an incremental theme object: there is a oneto-one relation between the process of burning and the parts of the house.

Another type of incremental argument is an incremental property:

\section{(12) John cooled the water.}

In contrast to (10) and (11), the internal argument is not an incremental theme here, since the progress of the event does not involve an increase in the amount of the water affected. At the same time, the changing property of the water, its temperature, is incremental with respect to the event, since a one-to-one relation does evolve between the event components 
and points on the water temperature scale. Verbs with a scale argument in their event structure are labeled degree achievements.

The last type of an incremental argument is an incremental path. Consider the example below:

John ran to the station.

In (13), there is an incremental relation between the event and the path (the route of John's running): the more John runs, the greater portion of the path is involved.

The light verb lart behaves inconsistently with verbs with different incremental arguments. The group of the incremental verbs which combine with the light verb lart with the least semantic impact is that of degree achievements, or verbs with an incremental property in their event structure. Namely, the light verb lart specifies the telic interpretation, and the complex predicate denotes a change of state of the object to some contextually relevant high degree:

$\begin{array}{llll}\text { a. vaca } & \text { at-in-e } & \text { tazat-sa } & \text { lart-r }^{j}-\partial \\ \text { V. } & \text { boot-P_3-OBJ } & \text { clean-CV_SIM } & \text { seat-PST-3SG }\end{array}$

'Vasya cleaned his boots'.

b. vaco tcask-a su-ba tol-dar-za lart-ri-a

V. cup-OBJ water-INS fill-CAUS-CV_SIM seat-PST-3SG

'Vasya filled the cup with water'.

c. vaco su azat-sa lart-ri-a

V. water heat-CV_SIM seat-PST-3SG

'Vasya heated the water'.

$\begin{array}{llll}\text { d. vaca } & \text { 6an-in-e } & \text { madak-la-t-sa } & \text { lart-rj-a } \\ \text { V. } & \text { sleeve-P_3-OBJ } & \text { short-VBZ-CAUS-CV_SIM } & \text { seat-PST-3SG }\end{array}$

'Vasya shortened his sleeves'.

In combination with verbs with an incremental theme, the light verb lart behaves differently depending on whether the object comes into existence during the event, disappears after it, or just changes its state or even remains the same. I distinguish four classes of verbs based on this 
parameter: verbs of creation, verbs of destruction ${ }^{8}$, verbs of impact on the object, and verbs with a non-patient incremental theme, respectively.

In combination with verbs of creation, the light verb lart simply forms complex predicates denoting accumulation of the created object:
a. vaca Gavraska yger-ze lart-ri-a
V. circle draw-CV_SIM seat-PST-3SG
'Vasya drew a circle'.

b. papi sarf $\quad 6 i k-s a \quad$ lart-rij-a

grandma scarf tie-CV_SIM seat-PST-3sG

'Grandma knitted a scarf'.

If a creation verb is not incremental, it combines with the light verb lart, but preferably, with a plural object:

c. ?anjo ul corat-sa lart-ri-a
A. son give.birth-CV_SIM seat-PST-3SG

'Anya gave birth to her son'.

d. anjo nomaj atca 6orat-sa lart-rij-z

A. many child give.birth-CV_SIM seat-PST-3SG

'Anya gave birth to many children'.

In combination with incremental verbs of destruction, the light verb lart behaves inconsistently. I have only three verbs of destruction in my sample with an incremental theme in their event structure: 6ondar 'burn', erëlder 'melt', and kajdar 'erase'. Admittedly, all the three verbs form complex predicates with different semantic output.

In combination with lart, the lexical verb 6ondar 'burn' forms complex predicates as in (16):
a. vaco kastriulj-a
6on-dar-za
lart-ri-a
$\mathrm{V}$.
saucepan-oBJ
burn-CAUS-CV SIM
seat-PST-3SG
'Vasya burnt the saucepan'.

\footnotetext{
${ }^{8}$ I use the terms "creation" and "destruction" in a "referential" sense: creation is a kind of event where a new object is to come into existence, while destruction is a kind of event where the object is to disappear.
} 
$\begin{array}{llll}\text { b. }{ }^{\%} \text { vaca } & \text { pørd-e } & \text { 6on-dar-za } & \text { lart-rij-a } \\ \text { V. } & \text { house-OBJ } & \text { burn-CAUS-CV_SIM } & \text { seat-PST-3SG }\end{array}$

'Vasya burnt the house to some extent / *completely'.

In (16a), there is no incremental theme interpretation: it is not true that the pan gradually becomes smaller in size through the process of burning. Instead, the complex predicate 6ondarza lart denotes some change of the incremental property similar to degree achievement: indeed, the pan gets increasingly stronger effect of burning during the process. The same is true of (16b), though it is pragmatically less natural and is thus rejected by some consultants.

In contrast, the other verb erëlder 'melt' in combination with lart denotes reaching the endpoint of the melting, i.e. the moment when the ice completely turns into water:
vaca par erël-der-ze
lart-rij-a
$\mathrm{V}$. ice melt-CAUS-CV_SIM seat-PST-3SG
'Vasya melted the ice (completely)'.

The third verb, kajdar 'erase' can combine with lart in only few idiolects where it denotes entering into a state (disappearance of the drawing):
'Vasya erased a drawing'.

Another verb that can be used in situations of destruction is synder 'extinguish'; in combination with lart, it forms a complex predicate with a completive meaning:
vaca vod-a syn-der-ze
V. fire-OBJ go.out-CAUS-CV_SIM seat-PST-3SG
'Vasya extinguished the fire'.

In this case it is not clear, however, whether the verb's object is indeed an incremental theme or a patient with an incremental property affected.

Overall, the behavior of the light verb lart with destruction verbs is inconsistent and needs further investigation. It is possible that a patient 
of a destruction verb should have an incremental property for this verb to combine with lart.

In combination with most incremental theme verbs denoting other types of change of state, the light verb lart also has a completive meaning, i.e. it denotes coverage of an incremental theme:

a. vacz oj soxala-za lart-r ${ }^{j}-\partial$

V. field plow-CV_SIM seat-PST-3sG

'Vasya plowed the field'.

b. vaco karda sarla-za lart-rij-ə

$\mathrm{V}$. fence paint-CV_SIM seat-PST-3sG

'Vasya painted the fence'.

c. vaca oraj sal-za lart-rij-a

V. floor sweep-CV_SIM seat-PST-3SG

'Vasya swept the floor'.

The only observed exclusion from this generalization is the class of consumption verbs, i.e. the verbs $6 i$ 'eat' and $\ddot{e}_{6}$ 'drink'. In contrast to the other verbs of this class, the light verb lart forms complex predicates with accumulative meaning, often with saturativity inference:

$\begin{array}{llll}\text { a. vaco } & \text { (sørbe) } & \text { si-ze } & \text { lart-rij-a } \\ \text { V. } & \text { soup } & \text { eat-CV_SIM } & \text { seat-PST-3SG }\end{array}$

'Vasya ate enough (soup)'.

b. val nomaj ë6-se lart-ri-a

3SG many drink-CV_SIM seat-PST-3SG

'He drank a lot'.

In (21a) and (21b), the culmination point of the denoted event is the contextually relevant moment of the agent's saturation with consumption. In contexts where the exhaustification of the object is specified, the light verb lart is prohibited:
*vaca pëdëm cørbe ci-ze lart-rí-a $\mathrm{V}$ totally soup eat-CV_SIM seat-PST-3SG
Int.: 'Vasya ate all the soup'. 
The same saturative meaning of complex predicates with lart arises in combination with verbs with an incremental object that does not change its state during the event:

$\begin{array}{llll}\text { vaca } & \text { kino-zam } & \text { pak-sa } & \text { lart-r }{ }_{-}^{j} \text {-a } \\ \text { V. } & \text { film-PL } & \text { watch-CV_SIM } & \text { seat-PST-3SG }\end{array}$

'Vasya had his fill of watching films'.

For example, the culmination point in (23) is not the moment when all the films are being watched, but the moment of Vasya's saturation with film watching, when it becomes obvious that he had seen enough movies. In other words, it seems that incremental argument is not used as a scale, on which lart operates; rather, the relevant scale is the scale of accumulation associated with the agent.

The last subpart of incremental verbs to consider here are verbs with an incremental path. In combination with verbs of motion, lart forms complex predicates that at first glance operate on a path scale:

$\begin{array}{lllll}\text { a. vaca } & \text { vizë } & \text { kilometr } & \text { is-se } & \text { lart-rí-ə } \\ \text { V. } & 3 & \text { kilometer } & \text { swim-CV_sim } & \text { seat-PST-3SG }\end{array}$

'Vasya swam for three kilometers'.

b.

$\begin{array}{lllll}\text { vaco } & \text { për } & \text { kilometr } & \text { t6op-sa } & \text { lart-r }^{j}-2 \\ \text { V. } & 1 & \text { kilometer } & \text { run-CV_SIM } & \text { seat-PST-3SG }\end{array}$

'Vasya ran for one kilometer'.

c. samoljot pin kilometr vë6-se lart-sa plane $\quad 1000$ kilometer fly-CV_SIM seat-CV_SIM

'A plane flew one thousand kilometers'.

It is not clear, however, whether the scale light verb lart operates on in these cases is a proper path scale; at least, it is not clear whether it is the only option. Sometimes native speakers translate sentences like (24) into Russian using the cumulative prefix $n a-$; for example, the verb from (24c) could be translated as Rus. naletat ${ }^{j}$ ' $\log$ [1000 kilometers]'. However, judging by the preliminary data, the light verb lart can be used in contexts where experiential interpretation is problematic: 
(25) vaca kil-den pocla-za skol-a sid-e

V. home-ABL begin-CV_SIM school-oBJ reach-CV_ATT

$$
\begin{aligned}
& \text { tsop-sa } \quad \text { lart-r' } j_{-} \partial \\
& \text { run-CV_SIM } \quad \text { seat-PST-3SG } \\
& \text { 'Vasya ran from home to school'. }
\end{aligned}
$$

Thus, in combination with incremental-path lexical verbs, lart can form a complex predicate either with incremental path, or accumulative "experiential" reading; though in any case, the degree of the effort must be contextually significant.

\subsection{The light verb lart and non-incremental lexical verbs}

Considered next are non-incremental lexical verbs combining with lart. The meaning of the resulting complex predicates can differ depending on whether the object undergoes change during the event.

In combination with some non-incremental verbs of a durative change of the state of the object, such complex predicates can denote a telic process of object accumulation:

a. vaca nomaj xot $6 \ddot{e} t-s e \quad$ lart-rij-a

V. many paper tear-CV_sIM sead-PST-3SG

'Vasya tore a lot of paper'.

b. vaca nomaj kajak tit-sa lart-rij-ə

V. many bird catch-CV_SIM seat-PST-SG

'Vasya caught a lot of birds'.

c. vaca vodo $60 r-z a$ lart-rij-a

V. wood chop-CV_SIM seat-PST-3SG

'Vasya chopped a lot of wood'.

Thus, (26a) describes a culmination point where the accumulation of paper reaches a contextually relevant high degree, while the degree of destruction of the paper is irrelevant. In fact, there is an evident similarity between such examples and the complex predicates formed from 
creation verbs: in both cases, an entity is created during the action. There are some restrictions on the formation of such cumulative complex predicates, discussed below in the analysis.

If the lexical verb denotes a durative event without a patientive object, the complex predicate has a cumulative interpretation, often with a saturativity inference. Thus, in combination with transitives with non-incremental theme objects (27a), as well as with activities (27b) or states (27c), the light verb lart forms complex predicates denoting that the agent has performed the action up to the satisfaction point:

a. vaca tcedtek sarsla-za lart-rí-a

V. flower smell-CV_SIM seat-PST-3SG

'Vasya had his fill of smelling the flower'.

b. vasa nomaj sek-se lart-r $r_{-}$-a

V. many jump-CV_SIM seat-PST-3sG

'Vasya jumped enough'.

c. vaco $64 r-z a \quad$ lart-ri-a

V. sleep-CV_sim seat-PST-3SG

'Vasya slept enough'.

In such cases, the accumulator of effect is not the object, but rather the subject: in (27a), it is the person who has satisfied his wish for smelling the flower; in (27b), it is the person who has achieved some effect (saturation or fatigue) as a result of his jumping; and in (27c), it is the person who has slept enough for some contextually relevant scale (most probably, a scale of wakefulness).

Finally, lart generally does not combine with verbs denoting a momentary change of state on a binary scale:

$$
\begin{aligned}
& \text { a. *vaca sarik sek-ter-ze lart-rij-a } \\
& \text { V. balloon burst-CAUS-CV_SIM seat-PST-3SG } \\
& \text { Int.: 'Vasya burst the balloon'. } \\
& \begin{array}{clll}
\text { b. *vacə } & \text { cëlëg-e } & \text { top-sa } & \text { lart-rij-a } \\
\text { V. } & \text { hat-OBJ } & \text { find-CV_SIM } & \text { seat-PST-3s }
\end{array} \\
& \text { Int.: 'Vasya found the hat'. }
\end{aligned}
$$


So, in (28a), the object entered the ungradable state of bursting (it is impossible to be more or less burst. The same holds for (28b).

Note that, in contrast to creatives, such verbs cannot combine with the light verb lart even with a plural object:
c. *
*vaco
nomaj
sarik sek-ter-ze
lart-rij-a
many
balloon burst-CAUS-CV_SIM
seat-PST-3SG
Int.: 'Vasya burst a lot of balloons'.

However, I found some examples where the light verb lart does combine with verbs denoting momentary events. Some of them are provided below:
a. vaco pet ${ }^{j}-a$
bulavka-ba ter-ze
lart-ri-a
V. P.-OBJ pin-INS poke-CV_SIM seat-PST-3SG
'Vasya pricked Petya with a pin'.
b. vaco jid-a tap-sa lart-rij-a
V. dog-OBJ kick-CV_SIM seat-PST-3sG
'Vasya kicked the dog'.

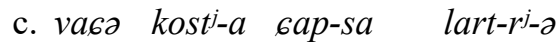
V. K.-OBJ hit-CV_SIM seat-PST-3SG
'Vasya hit Kostya'.

It is not clear whether one should consider such cases together with the other instances of the usage of lart, since there is no meaning of incremental change of a property arising in all the other examples. However, what these examples have in common with the rest is that they denote events with some effect produced on one of the arguments; and, furthermore, this effect is possibly gradable, because a bite, a kick, or a hit can be stronger or weaker. Thus, some scale may be activated in such sentences, with the only difference that it is not incremental to the process subevent. However, the presence of the scale should be proved in this case to avoid an ad hoc stipulation. In addition, it is not clear why the meaning (or implicature) of an accident arises in at least some of the consultants' translations. This case certainly needs further investigation.

Overall, the verb lart 'seat' is grammaticalized into a telicizing operator which can combine with (scalar!) non-ergative or transitive lexical 
verbs. It usually forms incremental predicates from verbs denoting durative events, but in the specific case of momentary events, it can presumably ${ }^{9}$ operate on a scale of the effect on the object, where possible. In addition, it requires a high enough grade on a scale. My analysis of this light verb is proposed in the next section.

The distribution of different meanings of the light verb lart with different classes of lexical verbs is summarized in Table 1 (p. 425) (recall that the light verb does not combine with unaccusatives or some of momentary event verbs).

Before moving on to the analysis, I need to admit that it is not completely clear whether the accumulative meaning of complex predicates with the light verb lart can emerge with any verbs that basically form complex predicates denoting a change of state of the object. However, even if this meaning is possible in some cases, it has not been detected during the elicitation: my consultants consistently translate complex predicates with the change-of-state interpretation, but never with accumulative meaning. Thus, my analysis addresses the basic, most natural interpretations of complex predicates with the light verb lart, while a more precise analysis of the distribution of the two meanings is certainly needed. Below, I will also comment on how the possible expansion of the accumulative meaning of lart may affect my analysis.

\section{Analysis}

To summarize, the core properties of the light verb lart mentioned above, are as follows. First, lart can form punctive complex predicates and thus function as a telicizing operator. Second, it can only combine with verbs with an external argument. Third, complex predicates with lart describe a kind of a (significant!) scalar change of the state of one of the arguments.

\footnotetext{
${ }^{9}$ It is not still clear whether the light verb lart in such cases has the same structure. It can be the case that there is "another" light verb lart in this context. This problem needs further investigation.
} 
Table 1. Distribution of the meanings of lart with different classes of lexical verbs

\begin{tabular}{|c|c|c|c|}
\hline \multicolumn{3}{|c|}{ Class of the lexical verb } & The meaning of the complex predicate \\
\hline \multirow{7}{*}{$\begin{array}{l}\text { Incremental } \\
\text { verbs }\end{array}$} & \multicolumn{2}{|c|}{$\begin{array}{l}\text { Verbs with incremental } \\
\text { property }\end{array}$} & $\begin{array}{l}\text { A change of state of the object to some } \\
\text { contextually relevant high degree }\end{array}$ \\
\hline & \multicolumn{2}{|c|}{ Verbs with incremental path } & $\begin{array}{l}\text { Accumulation of the object } \\
\text { (large path covered) }\end{array}$ \\
\hline & \multirow{5}{*}{$\begin{array}{l}\text { Verbs with } \\
\text { incremental } \\
\text { theme }\end{array}$} & $\begin{array}{l}\text { Verbs } \\
\text { of creation }\end{array}$ & Accumulation of the created object \\
\hline & & $\begin{array}{l}\text { Verbs } \\
\text { of destruction }\end{array}$ & \multirow[b]{2}{*}{ Completeness of the action } \\
\hline & & $\begin{array}{l}\text { Verbs } \\
\text { of impact } \\
\text { on the object }\end{array}$ & \\
\hline & & $\begin{array}{l}\text { Verbs with } \\
\text { a non- } \\
\text { patientive } \\
\text { incremental } \\
\text { theme }\end{array}$ & \multirow{3}{*}{ Contextual saturation of the agent } \\
\hline & & Ingestives & \\
\hline \multirow{3}{*}{$\begin{array}{l}\text { Non- } \\
\text { incremental } \\
\text { verbs }\end{array}$} & \multirow{2}{*}{ Durative } & $\begin{array}{l}\text { Verbs without } \\
\text { patientive } \\
\text { object }\end{array}$ & \\
\hline & & $\begin{array}{l}\text { Verbs with } \\
\text { patientive } \\
\text { object }\end{array}$ & Accumulation of the object \\
\hline & \multicolumn{2}{|c|}{ Non-durative } & $\begin{array}{l}\text { Suddenness of the action } \\
\text { (could be another meaning) }\end{array}$ \\
\hline
\end{tabular}

The most interesting property of complex predicates with lart is that the choice of the scale depends on the thematic properties of the lexical verb. Namely, the light verb chooses a scale associated with the object if the lexical verb denotes a scalar change of state of the object (unless this verb is ingestive or creative). In all other cases, viz. in those of ingestives, creatives, non-incremental durative verbs, or with verbs with 
non-patientive objects and unergatives, the light verb lart operates on the scale of accumulativity, associated with the agent. The key issue here is to identify the factor behind such a distribution of meanings.

Primitive syntactic and semantic factors cannot predict this distribution. It is not true that the light verb lart chooses the scale of the lexical verbs already containing it and introduces its own accumulative scale otherwise, because incremental verbs are split into two different groups. It is also false that the key factor is transitivity: transitive verbs behave with lart inconsistently. Finally, it is not completely true that the choice of scale depends on whether the lexical verb has a patient: for example, though the verbs tazat 'clean' and $6 i$ 'eat' both contain a patientive object in their argument structure, they belong to different groups in terms of the choice of the scale. In addition, it is not clear why the "default" scale is a scale of accumulation.

The first phase syntax theory can explain the distribution of the meanings of complex predicates with lart. This formal theory of event decomposition was first proposed in [Ramchand 2003] and later developed in [Lyutikova et al. 2006; Ramchand 2008a, 2009b; Lyutikova, Tatevosov 2014]. It claims that the event and argument structure of a predicate is represented in syntax by a combination of three heads (init, proc, and res) introducing the subevents of an event. Namely, init usually introduces a causing subevent, proc denotes a process subevent, and res introduces a resultant subevent or a resultant state. Each of the heads has specifiers and complements of its own. The specifier of an eventual head is an obligatory participant of this subevent. The eventual head init projects a specifier called Initiator (the participant-source of the causing subevent), proc introduces the Undergoer (the participant, physically involved in the process), and res introduces the Resultee (the holder of the resultant state). The complements of the subeventual heads are filled with other entities that specify the descriptive properties of the corresponding subevent. Such complements could be other eventual phrases, causally dependent on the subevent, or nominal or scalar arguments specifying some properties of the subevent. Such non-eventual arguments are called Rhemes.

The maximal projection of an event structure of the first phase syntax looks as follows: 


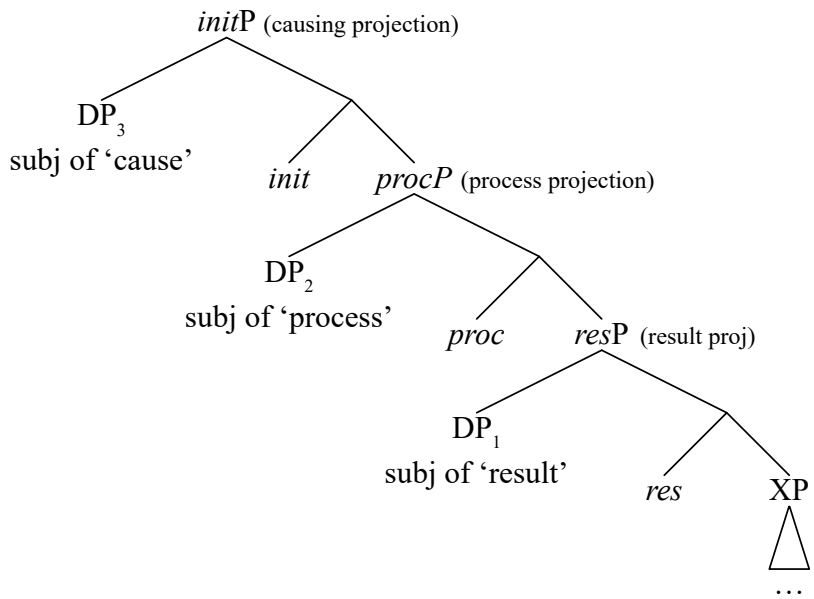

Fig. 1. A first phase syntax (copied from [Ramchand 2008a: 46])

This approach can differentiate a diversity of various event structures. The two crucial parameters are the set of the subevents and the reference relation between the specifiers. For example, unaccusatives differ from unergatives and transitives in that they lack initP (and hence cause the subevent and the Initiator), and unergatives differ from transitives in that the Initiator of unergatives is coreferential ${ }^{10}$ to the Undergoer, while the Initiator of transitives is not coreferential to their Undergoer.

Leaving aside many interesting formal details of the first phase syntax concerning various event structure issues, I will only touch on some key points of this framework, crucial for my analysis of the complex predicates. As shown above, despite their agentive nature, unergatives do have an Undergoer in their event structure, with this Undergoer usually coreferential to the Initiator. This structure logically follows from that of the first phase syntax: activities should contain proc, because this head is the source of dynamic inference, but at the same time, they should have init

${ }^{10}$ Note that in the first phase syntax, there is no restriction on how many theta-roles a DP could get: a single DP could, for example, get all the three roles (Initiator-Undergoer-Resultee) as with some agentive verbs of motion, such as arrive. 
to contain an external argument (the Initiator). Ramchand, however, proposes independent arguments for this analysis. For example, some contexts may allow transitivity with usually unergative verbs of motion, as illustrated in (30) (cited from [Ramchand 2008a: 128]):

a. Karena walked the dog.

b. Michael jumped the horse.

Moreover, Ramchand also analyzes some transitives as verbs with coreferential Initiators and Undergoers - despite the existence of a direct object. Namely, she analyses both creation verbs and ingestives as verbs where the subject is simultaneously the Initiator and the Undergoer, while the object is in the complement of proc (it is also called Path); see examples below (cited from [Ramchand 2008a: 20]:

(31) a. John painted a picture.

b. John painted a wall.

a. John painted me a picture.

b. ??John painted me a wall.

These examples illustrate the syntactic difference between the two usages of the verb paint (as a creation verb and as a verb denoting change of state), namely the inability of paint in the latter meaning to take a beneficiary argument. Ramchand argues that this contrast comes from the difference in the event structure: in its creative usage, paint takes the object as a Path, while the position of Undergoer is reserved for the future possessor of the creative entity: by default, it is Initiator itself, but it is possible to fill this position with another DP. In contrast, paint as a change-ofstate verb lacks such an ability: its Undergoer is obligatorily a DP denoting the changed entity, i.e. the object of painting.

On the other hand, only paint in its change-of-state usage can get a resultative secondary predication, since creation verbs do not project resP (the place of the complement of proc, where resP could merge, is already filled with the Path argument); the examples are cited from [Ramchand 2008a: 77]: 
a. John painted a wall red.

b. *John painted a picture red.

This specific behavior of ingestives and creatives is crucial for my research, since it explains why such verbs cluster with unergatives: they also have a coreferential Initiator and Undergoer.

The first phase syntax makes it possible to analyze derivations on the borderline between syntax and morphology, such as causatives and actional preverbs [Ramchand 2008a]. Particularly, this framework is well developed to adequately describe the structure of aspectual complex predicates in Indo-Arian languages [Ramchand 2008a, 2008b; Ozarkar, Ramchand 2018]. The authors analyze light verbs as verbs that have lost their lexical content, i.e. a capacity to denote their own situation, but preserved to some extent their event structure, i.e. the set of eventual heads and some argument structure restrictions.

Combining the ideas from [Ramchand 2008b; Ozarkar, Ramchand 2018], I argue that similar analysis is preliminarily applicable to light verbs in Chuvash, at least to the light verb lart 'seat' that can also form telic complex predicates.

The light verb lart (at least, in one of its meanings) forms complex predicates with the meaning of significant scalar change of state of thearguments of verbs with different event structure; thus, it is plausible that the event structure of such complex predicates is defined by lart rather than by the lexical verb.

Thus, if a light verb has its own event structure, this structure should be evident from its selective restrictions and actional properties. The fact that the light verb lart combines with only unergatives and transitives implies that it has an init head, as well as an Initiator corresponding to the external argument, or, informally speaking, an agent/ causer of the event. Further, since complex predicates with lart denote a kind of change of state with one of the arguments, there should be a proc head in its event structure, as well as an Undergoer, i.e. the patient of the event. Since the light verb lart forms telic complex predicates denoting entering a gradable state, the light verb lart should also project a Resultee and an eventual head res, responsible for the resultant state and requiring the resultant subevent to be gradable and denote a significant degree of a state. 
Finally, since the light verb lart can combine with both transitives and unergatives, the Initiator and the Undergoer can (not) be coreferential. As is standard in the first phase syntax, the Resultee is coreferential to the Undergoer, except for some very specific cases [Ramchand 2008a: 136-137]. Thus, the event structure of complex predicates with lart is as follows:

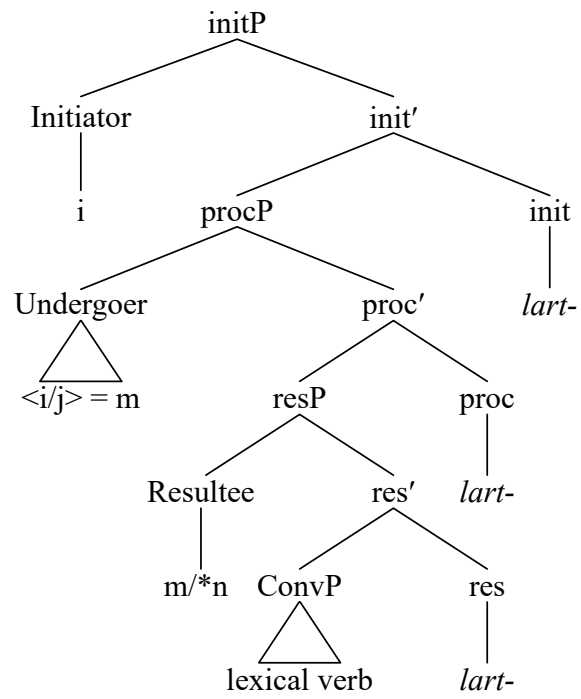

Fig. 2. The event structure of complex predicates with the light verb lart 'seat'

The structure of complex predicates with lart functions as follows. The light verb lart has an impoverished event structure without a lexical component, and it needs a lexical verb to fulfill the idiosyncratic component of its meaning. I tentatively ${ }^{11}$ argue that the light verb lart takes a converbal phrase in the complement of res (a similar analysis was proposed in [Ozarkar, Ramchand 2018] for Marathi telic predicates), and here events are identified via a formal semantic operation called generalized

${ }^{11}$ The position of the lexical verb phrase certainly needs a special proof. My analysis just mirrors the simple idea that the light verb takes a lexical verb phrase as its complement before it builds an event structure of its own. 
event identification [Tatevosov, Kiseleva 2019]. To avoid an explanation of the formal details of this operation, its essence is that the merged events intersect their truth conditions. A simplified informal explanation may be as follows. Consider the complex predicate in (34), equivalent to (4):

$$
\begin{aligned}
& \text { vaco su azat-sa lart-ri-a } \\
& \text { V. water heat-CV_SIM seat-PST-3SG }
\end{aligned}
$$

The verb azat 'heat' lexicalizes the event of heating, while the light verb lart has a bare event template and roughly means 'Initiator significantly changes a scalar state of the Undergoer-Resultee'. The light verb requires the semantics of the lexical verb to fulfill its event template, and the resultant complex predicate means 'Vasya as Initiator causes the water as Undergoer to enter the state of being significantly hotter as Resultee'.

While this analysis needs further development, my intention here is to give a general view on the possible formalization of complex predicate formation and show how the first phase syntax approach can explain some properties of such complex predicates.

Another important advantage of the analysis is that it also predicts the distribution of different meanings of the light verb lart, i.e. the choice of the scale and the argument changing its state during the event. Namely, it predicts that complex predicates with lart will denote a scalar change of state of the Undergoer of an event.

To be more precise, the analysis correctly predicts the distribution of "degree achievement" and accumulative meanings. If the Undergoer of the lexical verb is not coreferential to the Initiator, the complex predicate will have a meaning of a scalar change of the Undergoer (35):

$$
\begin{aligned}
& \text { a. vaco su azət-sa lart-r }{ }^{j}-\partial \\
& \text { V. water heat-CV_SIM seat-PST-3SG } \\
& \text { 'Vasya heated the water'. } \\
& \begin{array}{lll}
\text { b. vacə } & \text { can-in-e } \quad \text { madak-la-t-sa } & \text { lart-r }{ }^{j}-\partial \\
\text { V. } & \text { sleeve-P_3-OBJ short-VBZ-CAUS-CV_SIM } & \text { seat-PST-3SG } \\
\text { 'Vasya shortened his sleeves'. } &
\end{array}
\end{aligned}
$$


The impact of the light verb lart is invisible in this case, except for telicizing: since the light verb is already a degree achievement, it just maps its own event structure onto the structure of the lexical verb: the "empty" scale of lart is identified with the lexical scale of a degree achievement.

If the lexical verb has a non-coreferential Initiator and Undergoer, but it is not a degree achievement, then the possibility of complex predicate formation depends on whether it is possible to accommodate a kind of a scale. It is indeed possible if the Undergoer is itself an incremental argument, and lart works with incremental theme predicates as with degree achievements containing a mereological scale ${ }^{12}$ :
a. vaca par erël-der-ze
V. ice melt-CAUS-CV
lart-rij-a
$\mathrm{V}$. ice melt-CAUS-CV_SIM seat-PST-3SG
'Vasya melted ice'.
b. vaco oj soxala-za lart-rij-ə
V. field plow-CV_sim seat-PST-3SG
'Vasya plowed the field'.

It is possible that there are other cases where the scale is accommodated, but I have not come across them yet.

If a change of state is lexically specified and non-scalar, it is difficult to accommodate an appropriate scale, and the light verb lart is forbidden with such verbs (37):
a. *vaco sarik sek-ter-ze lart-ri-a $\mathrm{V}$ balloon burst-CAUS-CV_SIM seat-PST-3SG
Int.: 'Vasya burst the balloon'.
b. *vacə cëlëg-e top-sa lart-rí-ə
$\mathrm{V}$ hat-oBJ find-CV_SIM seat-PST-3SG
Int.: 'Vasya found the hat'.

\footnotetext{
12 The only observed exclusions are complex predicates from the verbs condar 'burn' (which has a trickier resulting meaning) and kajdar 'erase', which has the corresponding meaning in combination with lart but is incompatible with the light verb in some idiolects for some reason. Note, however, that complex predicates with condar still follow the general trend, since they denote events with an incremental change of the state of the object.
} 
If the Initiator and the Undergoer of the lexical verb are coreferential, the light verb lart forms complex predicates with accumulative interpretation. The more precise type of accumulation is contextually dependent: it could be accumulation of nutrients (38a), of information (38b), or of experience (38c):

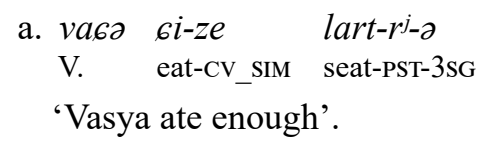

b. vasa kino-zam pak-sa lart-ri-a

V. film-PL watch-CV_sIM seat-PST-3SG

'Vasya watched films enough'.

$\begin{array}{lllll}\text { c. samoliot } & \text { pin } & \text { kilometr } & \text { vë6-se } & \text { lart-sa } \\ \text { plane } & 1000 & \text { kilometer } & \text { fly-CV_SIM } & \text { seat-CV_SIM }\end{array}$

'A plane flew one thousand kilometers'.

Presumably, an accumulative inference can be explained here by the fact that the light verb lart tries to scalarize the event where the Undergoer is coreferential to the Initiator. In fact, what we call the accumulative scale is a scale of any contextually possible impact made on the external argument during the event ${ }^{13}$. If this line is correct, then the analysis can predict accumulative meaning with such verbs without any additional assumptions.

Note that the first phase syntax correctly predicts cases where the accumulative meaning should arise: the common trait of all unergatives, transitive verbs of perceptive interaction with a theme object ${ }^{14}$, verbs

13 This idea goes in line with a similar suggestion in the analysis of the incrementalization phenomenon in Tuba [Tatevosov 2009].

14 The analysis of perception verbs such as pak 'watch' and sirsla 'smell' as containing coreferential Initiator and Undergoer comes from [Ramchand 2008a], where she discusses the behavior of causatives in Hindi / Urdu. Namely, she distinguishes a special class of 'ingestive' verbs which differ from the other transitives and behave similarly to unergatives in that they obligatorily decrease their valency after causativization; for more detail, see [Ibid.: 165-211]. Thus, Ramchand includes perception verbs 
of creation and ingestives is that the Initiator is coreferential with the Undergoer in their event structure, while the object, if present, is located in the Path position.

This analysis also explains the following contrast between verbs of creation and verbs of destruction:

a. 'an'z ul corat-sa lart-rí-z

A. son give.birth-CV_SIM seat-PST-3SG

'Anya gave birth to a son'.

b. *vaca sarik sek-ter-ze lart-rij-a

V. balloon burst-CAUS-CV_SIM seat-PST-3SG

Int.: 'Vasya burst the balloon'.

c. an's nomaj atca 6orat-sa lart-rij-a

A. many child give.birth-CV_SIM seat-PST-3SG

'Anya gave birth to many children'.

d. *vaca nomaj sarik sek-ter-ze lart-r-jo

$\mathrm{V}$. many balloon burst-CAUS-CV_SIM seat-PST-3SG

'Vasya burst many balloons'.

The difference between the two verbs in (39) is in the NP corresponding to the Undergoer. In the structure of sekter 'burst', the Undergoer is the object of bursting. Thus lart, operating on the destruction scale, fails to accommodate it because of its binary nature: while an object either can or cannot not be dead, a situation where it is, for instance, half-dead, is impossible. Therefore, (39b) is ungrammatical.

In contrast, the Undergoer of 6orat 'give birth to' is not an object; it is rather a subject of birthing according to the analysis provided in [Ramchand 2008a] for verbs of creation. The object of creation is a complement of proc, i.e. it is a Path argument. In this case, the contextually relevant

in the extended set of the already mentioned ingestives such as drink or eat. Note that the proposed "intransitive" event structure also logically follows from the definition of Undergoer: in cases of watching and smelling, it is rather the subject than the object that changes its state. 
scale is a scale of possession associated with the mother, and this scale is not binary: you can have a single child, two children, or more. That is why (39c) is grammatical.

Why is (39a) problematic then? I argue that it is infelicitous, because it describes the minimal possible grade of possession: a single child is the minimum you can get from birthing. Hence, the restriction on the significant degree is violated. Note that (39a) is a more natural sentence than $(39 b){ }^{15}$.

But why is (39d) ungrammatical? One could argue that here the analysis is incorrect, because sekter forms a scale of the quantity of the burst balloons, and it is non-binary. I think the problem is that lart requires here the incremental property of the whole Undergoer, and the scale of quantity does not fulfill this requirement. It is not true, that you burst balloons more if you burst more balloons. This is my explanation of (39d)'s infeliciity.

An interesting and at first glance problematic case arises in contexts where lart combines with non-incremental verbs with a patientive object (40):

a. vaca sip $\quad$ ët-se lart-ri-a

V. thread tear-CV_SIM sead-PST-3SG

'Vasya tore some threads'.

b. vaco voda $60 r-z a \quad$ lart-rij-a

V. wood chop-CV_SIM seat-PST-3sG

'Vasya chopped some wood'.

It is not clear which DP takes the Undergoer position here - the accumulator or the accumulated entity? In a way, both participants experience a change of state: the accumulator changes its state of wealth, while the accumulated entity changes its physical state. Moreover, these verbs, $6 \ddot{e} t$ 'tear' and 6or 'chop', are destruction verbs in their "prototypical" usages,

${ }^{15}$ In fact, some native speakers partially accept (39a) if Anya gives birth to her first son. Maybe it is an attempt to represent the birth of a single child as a significant possession, marking the opposition with a lack of any children. 
and it is not clear how something other than the object of destruction can be the Undergoer.

A possible solution to this problem is that these verbs are used here as creation verbs, and complex predicates denote a change of the accumulator's state of wealth, the same as postulated for creatives, ingestives, unergatives, and transitives without a patientive object. Note that the complex predicates in (41) do not describe a significant effect on the object as degree achievements usually do: the degree of the destruction is not important here. The only important value is the amount of the destructed resource accumulated - and this accumulation is a change of the agent's state.

Why not all destruction verbs can behave like that? For instance, why cannot sekter 'burst' or vëler 'kill' occur in such contexts, be these even forced accumulative contexts? I do not have a good answer for this, but a possible explanation is that verbs like $6 \ddot{e} t$ 'tear' or $60 r$ 'chop' differ from verbs like sekter 'burst' or vëler 'kill' in that they describe events that are more pragmatically compatible with the idea of accumulativity. One of the other possible explanations is that verbs like $6 \ddot{e} t$ 'tear' or $60 r$ 'chop' have a lexical specification of their processual and resultant subevents ${ }^{16}$, while verbs like vëler 'kill' idiosyncratically specify only the resultant state. Thus, the verbs from the first group are more "friendly" to the accumulative interpretation: they can at least save the processual part of their idiosyncratic constant, while the idiosyncratic component of result verbs is in complementary distribution with the possessive scale. However, it is still not clear whether sekter 'burst' is a verb of manner or result. As mentioned in Section 4, no strict distribution of the accumulative meaning is established, and some verbs with usually non-coreferential Initiator and Undergoer can form accumulative complex predicates in combination with lart. If it is the case, they must behave the same way as verbs like 6or 'chop' or tip 'tear', reinterpreted as verbs of creation.

Finally, the analysis is preliminarily applicable to cases where lart combines with verbs of momentary effect, though with a reservation: the

${ }^{16}$ See [Lyutikova et al. 2006] for similar suggestions for corresponding Karachay-Balkar verbs. 
scale provided by such a lexical verb is not incremental, it just characterizes the event in terms of the effect it had on the object, while this effect is still non-binary. However, further research is needed. Maybe the restriction the light verb lart applies to resultant state is not connected with scalarity directly: it could be that complex predicates with lart denote entering some pragmatically important state. Maybe the light verb lart has several meanings, only one of these relating to scalarity. Again, this is rather a topic for further research.

Overall, my analysis, made in the first phase syntax framework, can shed some light on why the light verb lart works the way it does: it still has some verbal properties defining its distribution and semantics, such as the presence of an external argument and the requirement of a scalar resultant state. The crucial thing this analysis predicts is the distribution of two meanings of the light verb and their semantic invariance. However, it is not completely clear how this event structure relates to its lexical meaning, and this topic needs further investigation.

\section{Conclusions and future perspectives}

A summary of the findings above could be presented as follows. The verb lart has grammaticalized into an actional operator forming punctive complex predicates. It can combine with lexical verbs with an external argument (transitives and unergatives) and form complex predicates with the meaning of reaching a significantly high degree of effect on the Undergoer of the event. According to my analysis, all these properties can be explained by the fact that the light verb lart has an event structure of its own containing eventual heads init, proc, and res, as well as Initiator, Undergoer, and Resultee, with the first two unspecified in terms of coreference. In addition, it specifies the resultant state that should be scalar, non-binary.

Admittedly, this analysis may have certain weak points. It is not clear, for example, how to explain the compatibility of lart with verbs like $6 a p$ 'hit' that are not obviously scalar. Nevertheless, the first phase syntax analysis helps to explain some important properties of the light verb, such as its 
interaction with the event and argument structure of lexical verbs. It is especially useful in that it explains the distribution of degree achievement and accumulative meanings as different instances of the scalar change of state of the Undergoer. However, more detailed analysis is needed.

Speaking of a typological perspective for this research, grammaticalization of verbs with the meaning SEAT found in Chuvash is not unique. This phenomenon takes place in many other Turkic languages; see [Grashchenkov 2015] for a general overview, or a description of the Tuba light verbs qoj 'stand' and sal 'put' in [Shluinskiy 2009]. Most such verbs form telic complex predicates, but as far as I know, the accumulative interpretation is rarely observed. The only known exception is the Hill Mari light verb šändäš 'seat, put' which looks very similar to lart: it is also grammaticalized into a telicizing operator denoting a scalar change of the Undergoer and also has accumulative and saturative interpretations [Kashkin 2018a, 2018b; Golosov 2019]. Since Hill Mari is areally close to Chuvash and, especially, to its Poshkart dialect, this similarity may be an areal feature, which evidently calls for a detailed typological survey.

\section{Abbreviations}

$1,2,3-1^{\text {st }}, 2^{\text {nd }}, 3^{\text {rd }}$ person; ABL — ablative case; CAUS - causative; CV_SIM neutral converb (also used as a past tense verb form); INS - instrumental case; LOC locative case; NPST — non-past tense; OBJ — objective case; $\mathrm{P}_{-} 3$ - possessive of the third person; PL — plural number; PST — past tense; SG — singular number; VBZ verbalizer.

\section{References}

Ashmarin 1923 - N. I. Asmarin. Opyt issledovaniya chuvashskogo sintaksisa [Chuvash Syntax Research Experience]. Pt. 2. Simbirsk: S. n., 1923.

Golosov 2019 - F. V. Golosov. Legkiye glagoly-telisizatory gornomariyskogo yazyka: grammaticheskaya semantika i distributsiya [Telicizing light verbs in Hill Mari: Semantics and distribution]. Acta Linguistica Petropolitana. Trudy Instituta lingvisticheskikh issledovaniy. 2019. Vol. XV. Pt. 2. P. 13-37. DOI: 10.30842/ alp2306573715201. 
Grashchenkov 2015 - P. V. Grashchenkov. Tyurkskiye konverby i serializatsiya: sintaksis, semantika, grammatikalizatsiya [Turkic Converbs and Serialization: Syntax, Semantics and Grammaticalization]. Moscow: Yazyki slavyanskoy kultury, 2015.

Kashkin 2018a - E. V. Kashkin. O semantike slozhnykh glagolnykh kompleksov v gornomariyskom yazyke: konstruktsii so znacheniyem dostizheniya predela [On semantics of complex verb constructions in Hill Mari: Completive constructions]. M. K. Amelina, A. A. Anufriyev, V. V. Dyachkov, N. V. Makeyeva, O. V. Popova, O. V. Sokolova (eds.). Problemy yazyka. Sbornik nauchnykh statey po materialam Shestoy konferentsii-shkoly "Problemy yazyka: vzglyad molodykh uchenykh" (12-14 marta 2018 g.) [Language Issues: Collection of articles based on the $6^{\text {th }}$ Conference "Language Issues: A Young Scholars' View" (March 12-14, 2018)]. Moscow: Institute of Linguistics RAS; Kantsler, 2018. P. 110-129. Kashkin 2018b - E. V. Kashkin. Grammatikalizatsiya gornomariyskikh glagolov pozitsii [Grammaticalization of Hill Mari posture verbs]. A. M. Ivanova, E. V. Fomin (comps., eds.). Yazykovyye kontakty narodov Povolzhya i Urala: sbornik statey XI Mezhdunarodnogo simpoziuma (Cheboksary, 21-24 maya 2018 g.) [Language Contacts in Povolzhye and Ural. Collection of articles of the $11^{\text {th }}$ International Symposium (Cheboksary, May 21-24, 2018)]. Cheboksary: Chuvash State University, 2018. P. 178-184.

Krifka 1989 - M. Krifka. Nominal reference, temporal constitution and quantification in event semantics. R. Bartsch, J. van Benthem, P. van Emde Boas (eds). Semantics and Contextual Expression. (Groningen-Amsterdam Studies in Semantics 11). Dordrecht: Foris Publications, 1989. P. 75-115. DOI: 10.1515/9783110877335005 .

Krifka 1992 - M. Krifka. Thematic relations as links between nominal reference and temporal constitution. I. A. Sag, A. Szabolsci (eds). Lexical Matters. (CSLI Lecture Notes 24). Stanford: Center for the Study of Language and Information, 1992. P. 29-53.

Lebedev 2016 - E. Ye. Lebedev. Aktsionsartovyye znacheniya slozhnoverbalnykh analiticheskikh form v chuvashskom yazyke [Actional Meanings of Complex Verbal Analytic Forms in Chuvash]. Cheboksary: Chuvash State Institute of Humanities, 2016.

Lyutikova et al. 2006 - E. A. Lyutikova, S. G. Tatevosov, M. Yu. Ivanov, A. B. Shluinskiy, A. G. Pazelskaya. Struktura sobytiya i semantika glagola v karachayevo-balkarskom yazyke [Event Structure and Semantics of the Verb in Karachay-Balkar]. Moscow: Gorky Institute of World Literature RAS, 2006.

Lyutikova, Tatevosov 2014 - E. Lyutikova, S. Tatevosov. Causativization and event structure. B. Copley, F. Martin (eds.). Causation in Grammatical Structures. 
(Oxford Studies in Theoretical Linguistics 52). Oxford: Oxford University Press, 2014. P. 279-327. DOI: 10.1093/acprof:oso/9780199672073.003.0011.

Ozarkar, Ramchand 2018 - R. Ozarkar, G. Ramchand. Structure matching and structure building in Marathi complex predicates. Journal of South Asian Linguistics. Vol 8. Iss. 1. P. 3-28.

Ramchand 2003 - G. Ramchand. First Phase Syntax. Manuscript. Oxford: University of Oxford, 2003.

Ramchand 2008a - G. Ramchand. Verb Meaning and the Lexicon: A First-Phase Syntax. (Cambridge Studies in Linguistics 116). Cambridge; New York: Cambridge University Press, 2008. DOI: 10.1017/CBO9780511486319.

Ramchand $2008 \mathrm{~b}$ - G. Ramchand. Lexical items in complex predications: Selection as underassociation. Nordlyd. Vol. 35. Iss. 1. P. 115-141. DOI: 10.7557/12.139.

Shluinskiy 2006 - A. B. Shluinskiy. Aktsionalnost i aspektualnyy pokazatel: konstruktsiya so vspomogatelnym glagolom il- v chuvashskom yazyke [Actionality and the aspect marker: Constructions with the verb il-in Chuvash]. Vestnik Moskovskogo Universiteta. Seriya 9, Filologiya. 2006. Vol. 1. P. 32-47.

Shluinskiy 2009 - A. B. Shluinskiy. Biverbalnyye konstruktsii i ikh leksicheskiye ogranicheniya [Biverbal constructions and their lexical restrictions]. S. G. Tatevosov (ed., comp.). Tubalarskiye etyudy [Tubalar Sketches]. Moscow: Gorky Institute of World Literature RAS Press, 2009. P. 6-53.

Tatevosov 2009 - S. G. Tatevosov. Aspektualnaya kompozitsiya [Aspectual composition]. S. G. Tatevosov (ed., comp.). Tubalarskiye etyudy [Tubalar Sketches]. Moscow: Gorky Institute of World Literature RAS, 2009. P. 78-133.

Tatevosov 2015 - S. G. Tatevosov. Aktsionalnost v leksike i grammatike: glagol i struktura sobytiya [Actionality in Lexicon and Grammar: Verb and Event Structure]. Moscow: Yazyki slavyanskoy kultury, 2015.

Tatevosov 2016 - S. G. Tatevosov. Glagolnyye klassy i tipologiya aktsionalnos$t i$ [Verbal Classes and Typology of Actionality]. Moscow: Yazyki slavyanskoy kultury, 2016.

Tatevosov, Kiseleva 2019 - S. G. Tatevosov, K. L. Kiseleva. Identifikatsiya sobytiy $\mathrm{v}$ prefiksalno-postfiksalnom slovoobrazovanii [Event identification in prefixal and postfixal derivations]. Vestnik Moskovskogo Universiteta. Seriya 9, Filologiya. 2019. Vol. 1. P. 7-35.

Yegorov 1957 - V. G. Yegorov. Materialy po grammatike sovremennogo chuvashskogo yazyka [Materials on the Grammar of Modern Chuvash]. Pt. 1: Morfologiya [Morphology]. Cheboksary: Chuvashgosizdat, 1957. 